\title{
Evaluation of Serum Iron and Transferrin in Idiopathic Nephrotic Syndrome Patients Attending Al-Hussein Pediatric Nephrology Clinic
}

\author{
Moftah Mohamed Rabeea*, Nayera Mahmoud Al-Akkad*, Gamal Zakariya El-Morsi**, Ahmed Elsayed \\ Darwish \\ Pediatric* and Clinical Pathology** Departments, Al-Azhar Faculty of Medicine.
}

\begin{abstract}
Background: Nephrotic syndrome is characterized by excessive urinary excretion of albumin and other intermediatedsize plasma proteins such as transferrin.. Excessive urinary losses of transferrin can produce low serum transferrin level that may lead to low plasma iron concentration and consequently the development of iron resistant microcytic hypochromic anemia. The aim of the work to evaluate changes in serum iron and transferrin and the relationship between the serum and urinary transferrin in the active and remission state of nephrotic syndrome

Patients and methods: The present work included fifty children with idiopathic nephrotic syndrome (INS), divided into 2 groups: group A (25 cases in activity) and group B (25 cases in remission). These two groups were age and sex matched with a mean age of $(7.74 \pm 2.45)$. All patients in this work were clinically evaluated together with routine laboratory investigations. Serum albumin and urinary alb. /creatinine were assessed. Levels of serum iron, serum ferritin, serum transferrin and urinary transferrin were measured.
\end{abstract}

Results: This work shows that the level of hemoglobin, MCV, HCT were statistically significantly lower in the cases in active state than cases in remission. The mean serum iron, serum ferritin and serum transferrin were significantly lower in the cases in active state than in the cases in remission. The mean urinary transferrin was statistically significantly higher in the cases in active state than in the cases with remission.

Conclusion: Urinary transferrin can be considered a reliable parameter for early prediction of iron deficiency anemia in children with active nephrotic syndrome.

Key Words: Hemoglobin (HG), Mean corpuscular volume (MCV) Albumin/creatinine ratio (alb. /creat) iron deficiency anemia ,serum iron ,transferrin

\section{Introduction and aim of the work}

Iron is essential for most living organisms. It is a component of hemoglobin, myoglobin as well as a number of enzymes such as cytochrome oxidase, xanthine oxidase, peroxidase and catalase ${ }^{(\mathbf{1})}$. Iron is derived from dietary ingestion and it is present in red meat, liver, eggs, green leafy vegetables and fortified cereal products ${ }^{(2)}$. Transportation of iron is through the mucosal cells of the upper small intestine by the plasma protein transferrin. Transferrin synthesis occurs primarily in the liver and appears to be related to the level of iron storage ${ }^{(3)}$. Childhood nephrotic syndrome characterized by heavy proteinuria results in low plasma albumin and odema (4). The most common age for nephrotic syndrome is between 1.5 and 8 years ${ }^{(5)}$. It is characterized by marked urinary excretion of albumin and other intermediated-size plasma proteins such as transferrin (6). Transferrin is important glycoprotein for iron transport between sites of absorption and storage and use in the body. In nephrotic syndrome, excessive urinary losses can produce low serum transferrin level that may lead to decrease serum iron level ${ }^{(7)}$, patients with nephrotic syndrome commonly have microcytic hypochromic anemia $(6)$.

The aim of the work is to evaluate changes in serum iron and transferrin and the relationship between the serum and urinary transferrin in the active and remission state of nephrotic syndrome.

\section{PATIENTS AND METHODS}

This study is a cross-sectional included fifty children with idiopathic nephrotic syndrome; from those attending the pediatric nephrology clinic, Al-Hussein University Hospital; and who were under regular follow up. During the period from July 2017 to Augustl 2018. Diagnostic criteria for INS were based on the International Study of Kidney Disease in Children.They were 22 males and 28 females. Their ages ranged from 4 -14 years.

Inclusion criteria: included children with wellestablished INS with preserved renal function, and under regular followed-up at Al-Hussein pediatric nephrology clinic.

Exclusion criteria: Patients with renal impairment patients with any manifestations of systemic disease or patients with secondary nephrotic syndrome.

The patients were classified into 2 groups:

Group A: This group included 25 nephrotic patients in activity either $1^{\text {st }}$ time or relapser (recurrence of severe proteinuria $>40 \mathrm{mg} / \mathrm{m}^{2} / \mathrm{h}$ or urine albumin dipstick $>2+$ on 3 successive days, often with a recurrence of edema after withdrawal of steroid therapy. It included 11 males 
and 14 females, their ages ranged from $4.17-13.17$ years with a mean age is $(8.12 \pm 2.58)$ years.

Group B: This group included 25 nephrotic patients in remission (marked reduction in proteinuria to $<4$ $\mathrm{mg} / \mathrm{m}^{2} / \mathrm{h}$ or urine albumin dipstick of 0 to trace for 3 consecutive days in association with resolution of edema). It included 11 males and 14 females, their ages ranged from $4.83-14.08$ years with a mean age is $(7.36$ \pm 2.30 ) years.

Ethical aspects: The Ethical Committees of Al-Azhar Faculty of Medicine and Pediatric Department approved the study. Informed consent was obtained from parents of all included children. The research protocol did not interfere with any medical recommendations or prescriptions. The aim of the study and all investigations as well as the risks and benefits of the study have been explained to the parents of the patients The follow-up of the INS patients guaranteed even in cases of refusal to participate in the study

All studied patients were subjected to the following: 1-Detailed history taking laying stress on: Symptoms of nephrotic syndrome, duration of the disease, response to steroid therapy, frequency of relapses, other medications and complications of steroid therapy.

2-Careful clinical examination laying stress on: - Blood pressure measurement and sign of edema. • Complications of steroid therapy. - Systemic examination include all body systems. - Manifestation of any systemic disease.

3-Laboratory investigations including:

A- Routine investigations including: - CBC, CRP and ESR.

B- Investigations for nephrotic syndrome: serum albumin, urine albumin/creatinine ratio.

C- Serum iron, total iron binding capacity, serum ferritin, serum transferrin and urinary transferrin

\section{Sample collection}

CBC sample was collected under complete aseptic conditions from venous blood that had been anticoagulated with ethylene diamine tetra-acetic acid (EDTA) and thoroughly mixed, which is essential for accurate test results. Test was performed within 6 hours of obtaining the blood specimen because some test results are altered by longer periods of storage, the sample was then analyzed in an automated blood counter instrument. Serum sample was collected from venous blood in plain sterile tubes which were allowed to clot undisturbed for one hour at room temperature. Tubes were centrifuged and the supernatant serum was then pipette into another tube and centrifuged again. The supernatant serum was then transferred to tubes for testing. Urine samples were taken from patients in clean containers, complete urinary albumin/creatinine ratio was done, and another sample for urinary transferrin.

\section{Serum transferrin and urinary transferrin}

Principle of the Method: In an immunochemical reaction, the proteins contained in the human serum or urine sample form immune complexes with specific antibodies. These complexes scatter a beam of light passed through the sample. The result is evaluated by comparison with a standard of known concentration.

Serum samples are automatically diluted 1:20 with $\mathrm{N}$ Diluent and measured. Transferrin in urine is measured from undiluted samples using a separate assay protocol if the readings obtained were outside the measuring range, the assay was repeated using a higher or lower dilution of the sample (not in the urinary transferrin assay protocol $^{\text {( 8) }}$

\section{Statistical analysis of the data}

Data were fed to the computer and analyzed using IBM SPSS software package version 20.0. (Armonk, NY: IBM Corp). Qualitative data were described using number and percent. The Kolmogorov-Smirnov test was used to verify the normality of distribution. Quantitative data were described using range (minimum and maximum), mean, standard deviation and median. Significance of the obtained results was judged at the 5\% level.

\section{The used tests were:}

Pearson coefficient; to correlate between two normally distributed quantitative variables

Positive $=$ increase in the independent variable leads to increase in the dependent variable

Negative $=$ increase in the independent variable leads to decrease in the dependent variable 
- ROC curve was used to determine cut off value

The following statistics can be defined:

Sensitivity: probability that a test result will be positive when the disease is present (true positive rate, expressed as a percentage)

Specificity: probability that a test result will be negative when the disease is not present (true negative rate, expressed as a percentage)
Positive predictive value (PPV): probability that the disease is present when the test is positive (expressed as a percentage)

Negative predictive value (NPV): probability that the disease is not present when the test is negative (expressed as a percentage).

\section{RESULTS}

\section{Results: the results of the present study are shown in the following tables and figures}

Table (1): Comparison between the two studied groups of cases according to age and sex

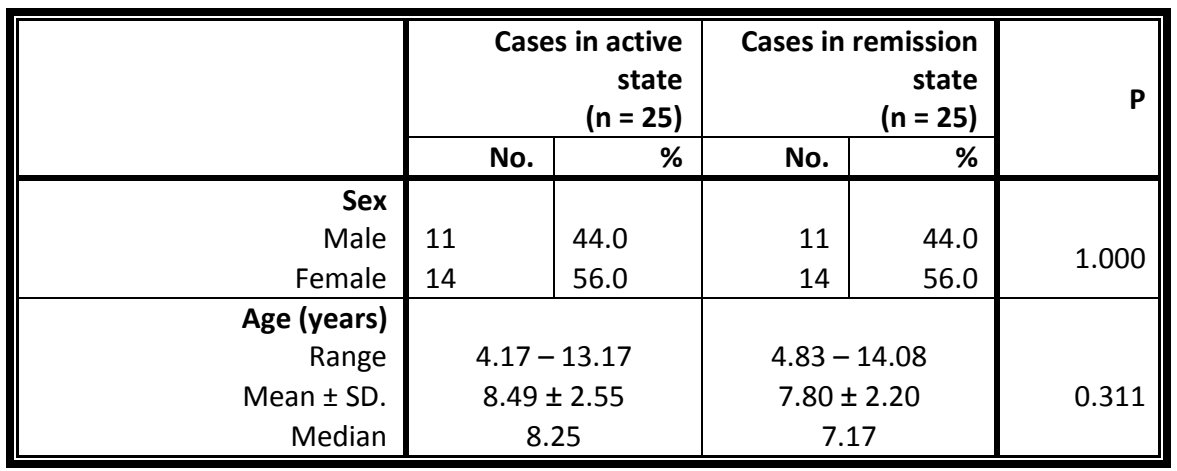

No statistically significant difference between the two groups.

Table (2): Comparison between the two studied groups of cases according to age of onset and duration of nephrotic syndrome

\begin{tabular}{||r|r|r|l||}
\hline & $\begin{array}{r}\text { Cases in active } \\
\text { state } \\
(\mathbf{n = 2 5}\end{array}$ & $\begin{array}{r}\text { Cases in remission } \\
\text { state } \\
(\mathbf{n = 2 5})\end{array}$ & $\mathbf{P}$ \\
\hline Age of onset & & & \\
Range. & $2.25-7.0$ & $3.08-6.78$ & \\
Mean \pm SD. & $4.75 \pm 1.35$ & $4.76 \pm 0.83$ & 0.968 \\
4 Median & 4.67 & 4.67 & \\
\hline Duration (years) & & $1.0-8.42$ & \\
Range & $0.25-8.58$ & $3.02 \pm 1.81$ & 0.109 \\
Mean \pm SD. & $3.73 \pm 2.08$ & 2.67 & \\
Median & 3.92 & & \\
\hline
\end{tabular}

No statistically significant difference between the two groups 
Table (3): Comparison between the two studied groups of cases according to weight and height

\begin{tabular}{|r|r|c|c|}
\hline & $\begin{array}{r}\text { Cases in active } \\
\text { state } \\
(\mathbf{n}=\mathbf{2 5})\end{array}$ & $\begin{array}{r}\text { Cases in remission } \\
\text { state } \\
(\mathbf{n}=\mathbf{2 5})\end{array}$ & $\mathbf{P}$ \\
\hline Weight (kg) & & & \\
Range & $20.0-55.0$ & $17.0-40.0$ & \multirow{2}{*}{$0.001^{*}$} \\
Mean \pm SD. & $30.40 \pm 7.57$ & $23.84 \pm 5.23$ & \\
Median & 30.0 & 23.0 & \\
\hline Height (cm) & & & \\
Range & $107.0-150.0$ & $105.0-160.0$ & \\
Mean \pm SD. & $125.6 \pm 11.78$ & $122.6 \pm 11.87$ & 120.0 \\
Median & 122.0 & 120.0 & \\
\hline
\end{tabular}

*There is a statistically significant difference between the two groups as regard to the weight but there is no significant difference in the height

Table (4): Comparison between the two studied groups according to blood pressure

\begin{tabular}{||l|c|c|c|c|}
\hline \multirow{2}{*}{ Blood pressure } & \multicolumn{2}{|c|}{$\begin{array}{c}\text { Cases in active state } \\
\text { (n= 25) }\end{array}$} & \multicolumn{2}{c|}{$\begin{array}{c}\text { Cases in remission } \\
\text { state } \\
\text { (n= 25) }\end{array}$} \\
\cline { 2 - 5 } & No. & $\%$ & No. & $\%$ \\
\hline \multirow{2}{*}{ Normal systolic blood pressure } & 25 & 100.0 & 25 & 100.0 \\
Normal diastolic blood pressure & 25 & 100.0 & 25 & 100.0 \\
Hypertension & 0 & 0 & 0 & 0 \\
\hline
\end{tabular}

Normal systolic and diastolic blood pressure for age, sex and height according to reference range of blood pressure in Nelson text book of pediatrics $20^{\text {th }}$ edition

No statistically significant difference between two groups

Table (4): Complete blood count in the two studied groups

\begin{tabular}{|c|c|c|c|}
\hline CBC & $\begin{array}{r}\text { Cases in active } \\
\text { state } \\
(\mathrm{n}=25)\end{array}$ & $\begin{array}{r}\text { Cases in remission } \\
\text { state } \\
(\mathrm{n}=25)\end{array}$ & $\mathbf{P}$ \\
\hline $\mathrm{HB}(\mathrm{g} / \mathrm{dl})$ & & & \\
\hline $\begin{array}{r}\text { Mean } \pm \text { SD } \\
\text { Median }\end{array}$ & $\begin{array}{c}9.72 \pm 0.42 \\
9.70\end{array}$ & $\begin{array}{c}12.36 \pm 0.58 \\
12.30\end{array}$ & \\
\hline $\begin{array}{r}\text { MCV(fl) } \\
\text { Mean } \pm \text { SD } \\
\text { Median }\end{array}$ & $\begin{array}{c}71.38 \pm 4.60 \\
73.40\end{array}$ & $\begin{array}{c}77.39 \pm 3.42 \\
77.80\end{array}$ & \\
\hline $\begin{array}{r}\text { HCT(\%) } \\
\text { Mean } \pm \text { SD. } \\
\text { Median }\end{array}$ & $\begin{array}{c}29.16 \pm 1.26 \\
29.10\end{array}$ & $\begin{array}{c}36.35 \pm 1.98 \\
36.0\end{array}$ & \\
\hline $\begin{array}{r}\text { RDW (\%) } \\
\text { Mean } \pm \text { SD. } \\
\text { Median } \\
\end{array}$ & $\begin{array}{c}21.30 \pm 5.17 \\
21\end{array}$ & $\begin{array}{c}12.80 \pm 2.79 \\
13\end{array}$ & $<0.01$ \\
\hline $\begin{array}{r}\text { TLC(count/mm3) } \\
\text { Mean } \pm \text { SD } \\
\text { Median }\end{array}$ & $\begin{array}{c}8.36 \pm 1.58 \\
8.15\end{array}$ & $\begin{array}{c}5.45 \pm 0.55 \\
5.50\end{array}$ & $<0.01$ \\
\hline $\begin{array}{r}\text { PLT(count/mm3) } \\
\text { Mean } \pm \text { SD } \\
\text { Median }\end{array}$ & $\begin{array}{c}418.9 \pm 24.97 \\
419.0\end{array}$ & $\begin{array}{c}244.6 \pm 26.19 \\
254.0\end{array}$ & $<0.01$ \\
\hline
\end{tabular}

* There is a significant difference between two groups in all CBC parameters 
Evaluation of Serum Iron and Transferrin in Idiopathic...

Table (5): Comparison between the two studied groups according to serum albumin and Urine albumin / creatinine ratio

\begin{tabular}{|r|c|c|c|}
\hline & $\begin{array}{r}\text { Cases in active } \\
\text { state } \\
(\mathbf{n = 2 5 )}\end{array}$ & $\begin{array}{r}\text { Cases in remission } \\
\text { state } \\
(\mathbf{n}=\mathbf{2 5})\end{array}$ & $\mathbf{P}$ \\
\hline S. Albumin (g/dl) \\
Range & $1.70-3.0$ & $3.20-4.10$ & \\
Mean \pm SD. & $2.46 \pm 0.39$ & $3.65 \pm 0.28$ & $<0.001^{*}$ \\
Median & 2.50 & 3.60 & \\
\hline Urine albumin / creatinine & & & \\
ratio & $386.1 \pm 27.74$ & $16.44 \pm 4.81$ & 18.0 \\
Mean \pm SD. & 387.0 & & \\
Median & & & \\
\hline
\end{tabular}

*There is significant difference between the two groups as regard s. albumin and Urine albumin / creatinine ratio

Table (6): Comparison between the two studied groups according to specific laboratory data

\begin{tabular}{|c|c|c|c|}
\hline Specific lab & $\begin{array}{c}\text { Cases in active } \\
\text { state } \\
(\mathbf{n}=\mathbf{2 5}) \\
\end{array}$ & $\begin{array}{c}\text { Cases in remission } \\
\text { state } \\
(\mathrm{n}=\mathbf{2 5})\end{array}$ & $\mathbf{p}$ \\
\hline $\begin{array}{r}\text { Serum iron }(\mu \mathrm{g} / \mathrm{ml}) \\
\text { Mean } \pm S D . \\
\text { Median }\end{array}$ & $\begin{array}{c}0.19 \pm 0.05 \\
0.20\end{array}$ & $\begin{array}{c}0.73 \pm 0.21 \\
0.70\end{array}$ & \\
\hline $\begin{array}{r}\text { TIBC }(\mu \mathrm{g} / \mathrm{dl}) \\
\text { Mean } \pm \text { SD } \\
\text { Median } \\
\end{array}$ & $\begin{array}{c}562.6 \pm 42.06 \\
553.0 \\
\end{array}$ & $\begin{array}{c}312.6 \pm 52.81 \\
300.0 \\
\end{array}$ & \\
\hline $\begin{array}{r}\text { Serum Ferritin }(\mathbf{n g} / \mathbf{m l}) \\
\text { Mean } \pm S D . \\
\text { Median }\end{array}$ & $\begin{array}{c}4.68 \pm 1.65 \\
4.0 \\
\end{array}$ & $\begin{array}{c}152.7 \pm 19.94 \\
144.0\end{array}$ & \\
\hline $\begin{array}{r}\text { Serum Transferrin }(\mathbf{m g} / \mathbf{d l}) \\
\text { Mean } \pm \text { SD. } \\
\text { Median }\end{array}$ & $\begin{array}{c}136.3 \pm 12.41 \\
135.0\end{array}$ & $\begin{array}{c}253.2 \pm 27.04 \\
253.0\end{array}$ & \\
\hline $\begin{array}{r}\text { Urinary Transferrin }(\mathbf{m g} / \mathbf{d l}) \\
\text { Mean } \pm \text { SD. } \\
\text { Median }\end{array}$ & $\begin{array}{c}2.62 \pm 0.35 \\
2.60\end{array}$ & $\begin{array}{c}0.17 \pm 0.03 \\
0.17\end{array}$ & \\
\hline
\end{tabular}

*There is a marked significant difference between the two groups as regard to Serum iron, TIBC, Serum Ferritin, Serum Transferrin and Urinary Transferrin.

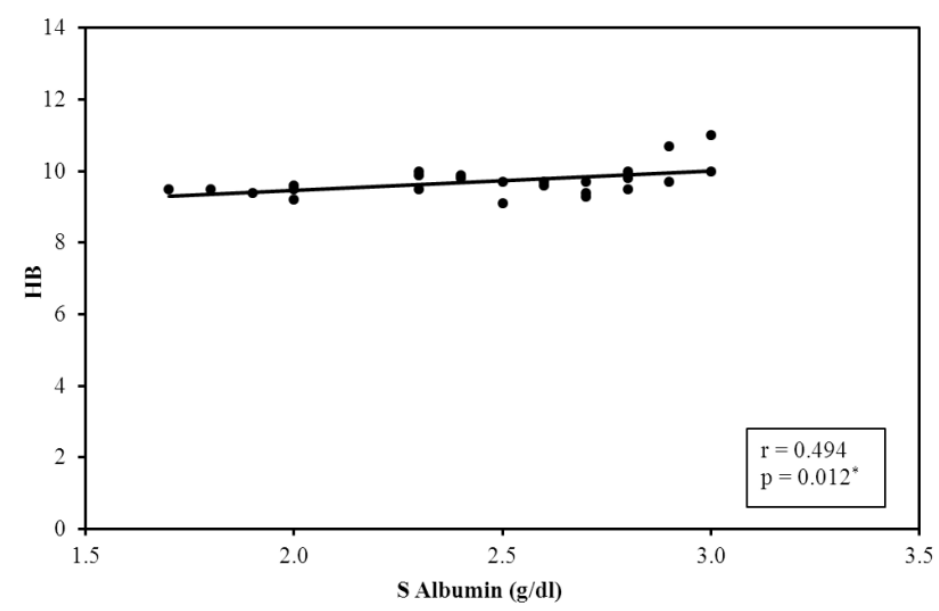


Figure (1): Correlation between $\mathrm{S}$ albumin $(\mathrm{g} / \mathrm{dl})$ and $\mathrm{HB}$ in cases in active state (+ve correlation)

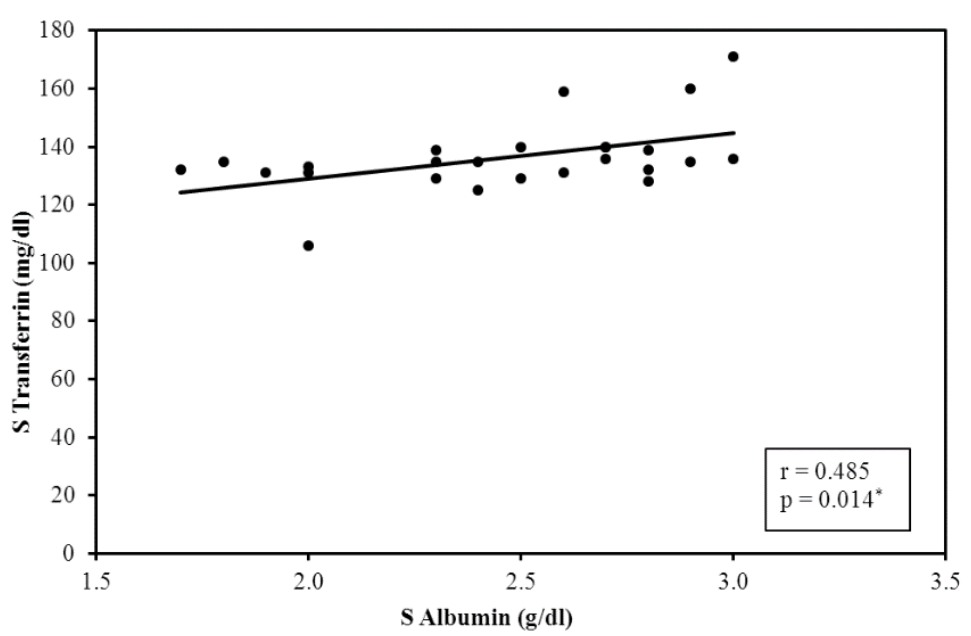

Figure (2): Correlation between $\mathrm{S}$ albumin $(\mathrm{g} / \mathrm{dl})$ and $\mathrm{S}$ transferrin $(\mathrm{mg} / \mathrm{dl})$ in cases in active state (+ve correlation)

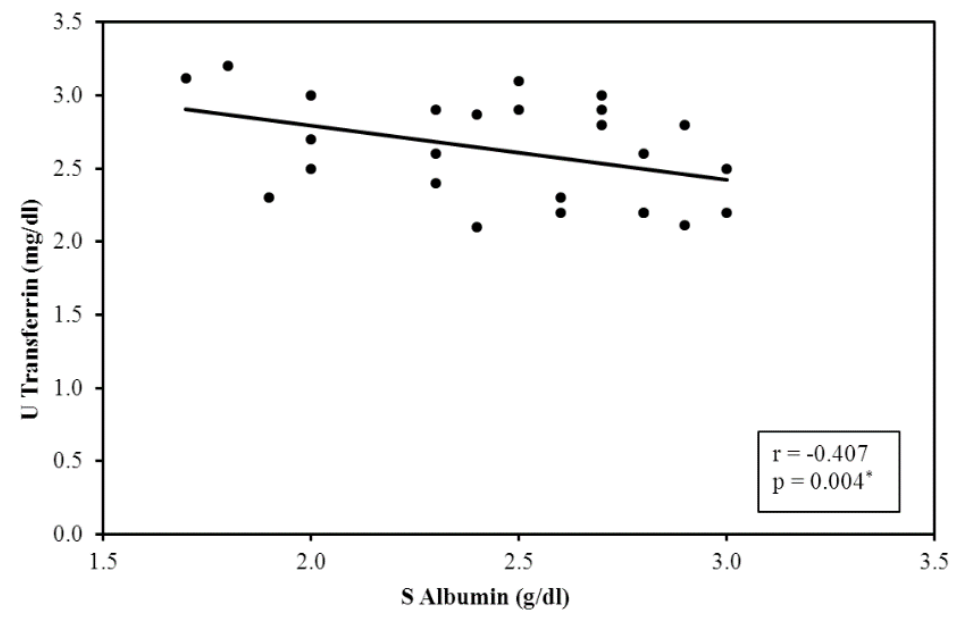

Figure (3): Correlation between $\mathrm{S}$ albumin $(\mathrm{g} / \mathrm{dl})$ and $\mathrm{U}$ transferrin $(\mathrm{mg} / \mathrm{dl})$ in cases in active state (-ve correlation)

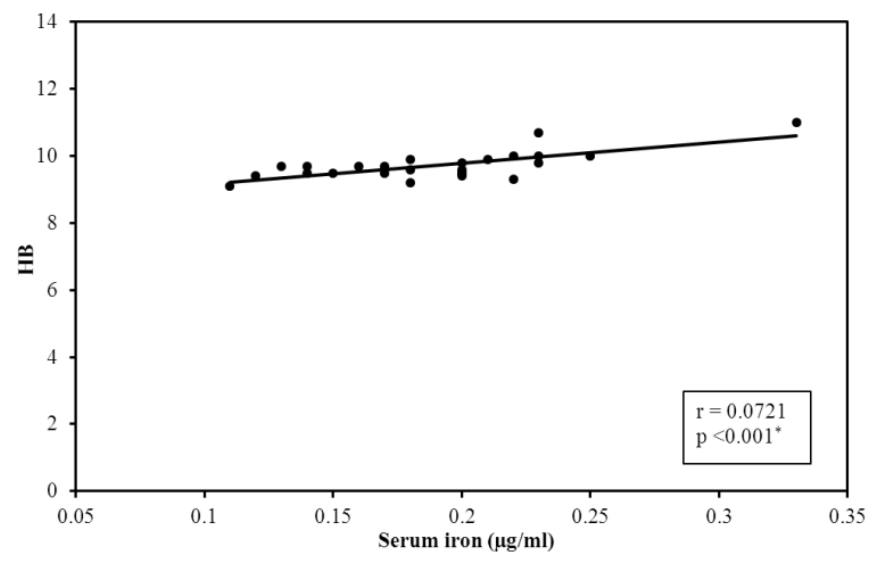

Correlation between serum iron $(\mu \mathrm{g} / \mathrm{ml})$ and $\mathrm{HB}$ in cases in active state (+ve correlation) Figure (4): 
Evaluation of Serum Iron and Transferrin in Idiopathic...

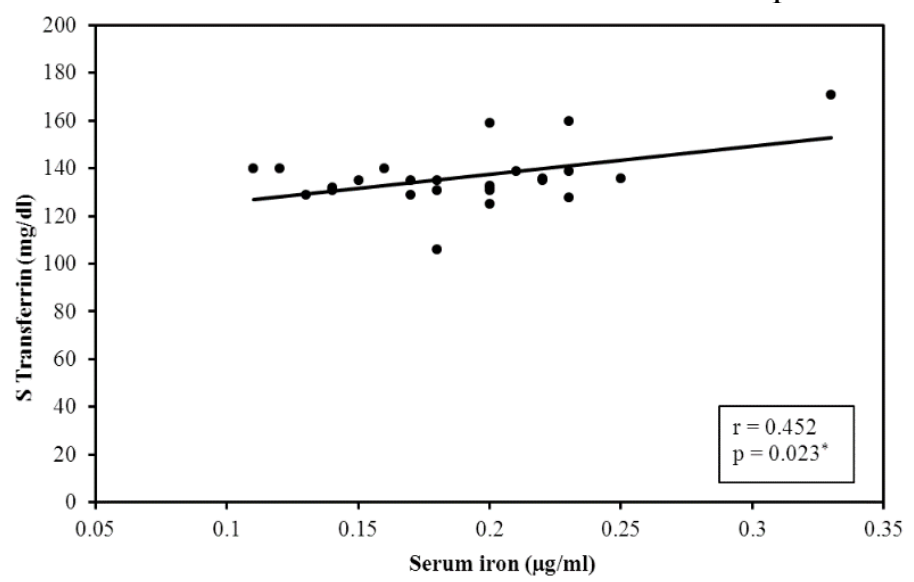

Figure (5): Correlation between serum iron $(\mu \mathrm{g} / \mathrm{ml})$ and $\mathrm{S}$ transferrin $(\mathrm{mg} / \mathrm{dl})$ in cases in active state group (+ve correlation)

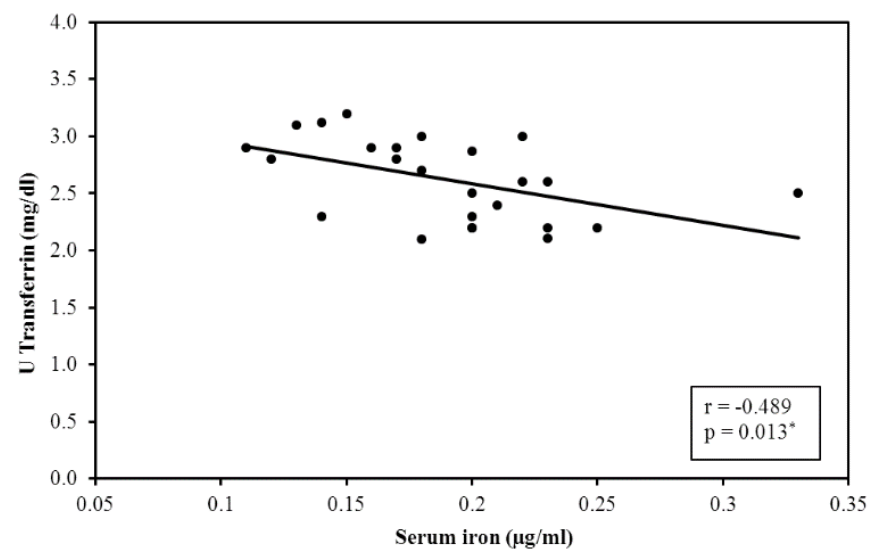

Figure (6): Correlation between Serum iron $(\mu \mathrm{g} / \mathrm{ml})$ and $\mathrm{u}$ transferrin $(\mathrm{mg} / \mathrm{dl})$ in cases in active state (-ve correlation)

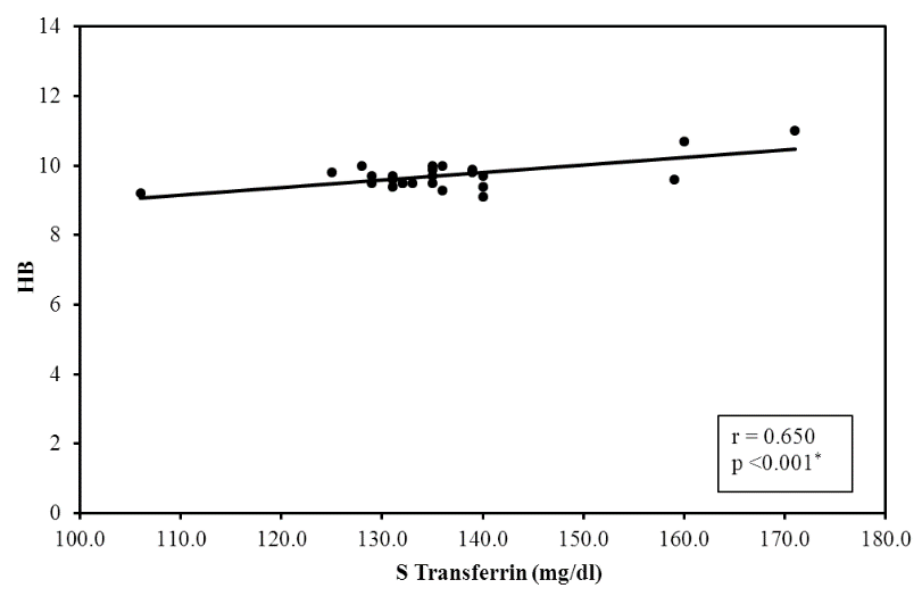

Figure (7): Correlation between S Transferrin ( $\mathrm{mg} / \mathrm{dl})$ and HB in cases in active state (+ve correlation) 


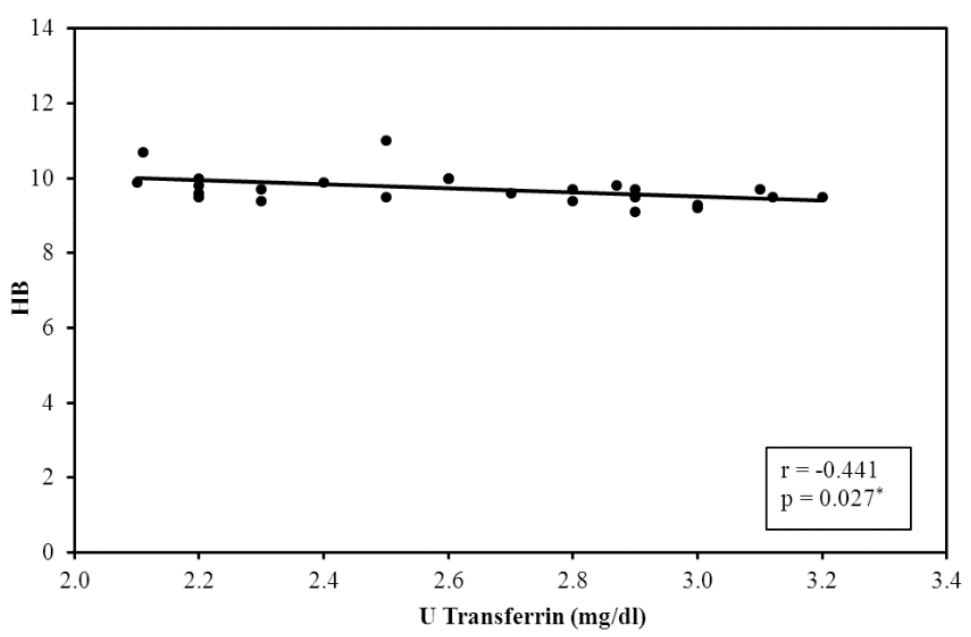

Figure (8): Correlation between U Transferrin ( $\mathrm{mg} / \mathrm{dl})$ and HB in cases in active state (-ve correlation)

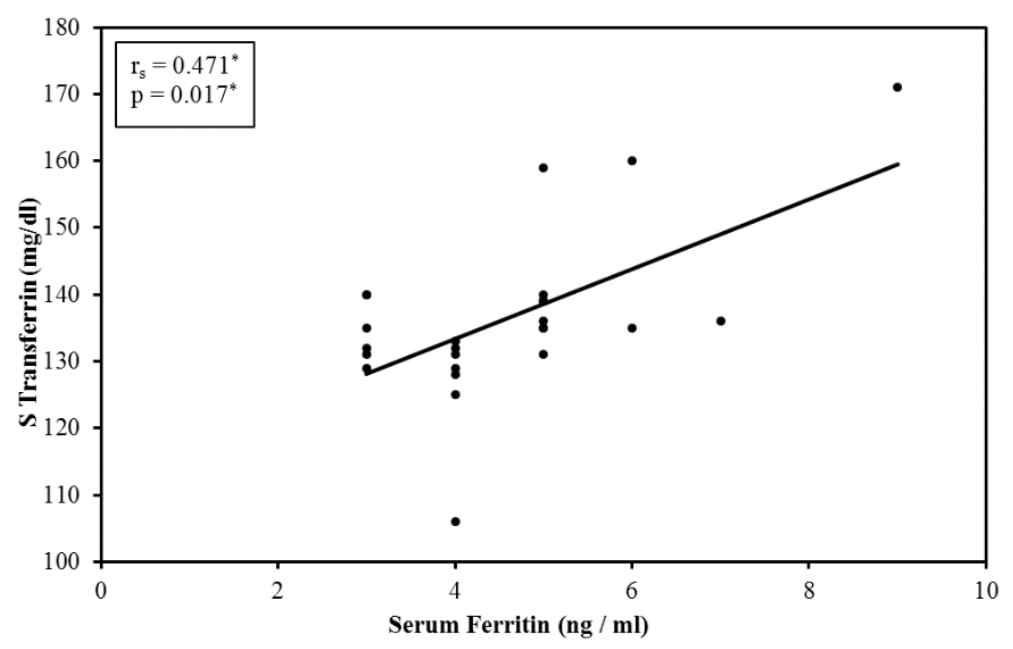

Figure (9): Correlation between serum ferritin $(\mathrm{ng} / \mathrm{ml}$ ) and S Transferrin ( $\mathrm{mg} / \mathrm{dl})$ in Cases in active state (+ve correlation)

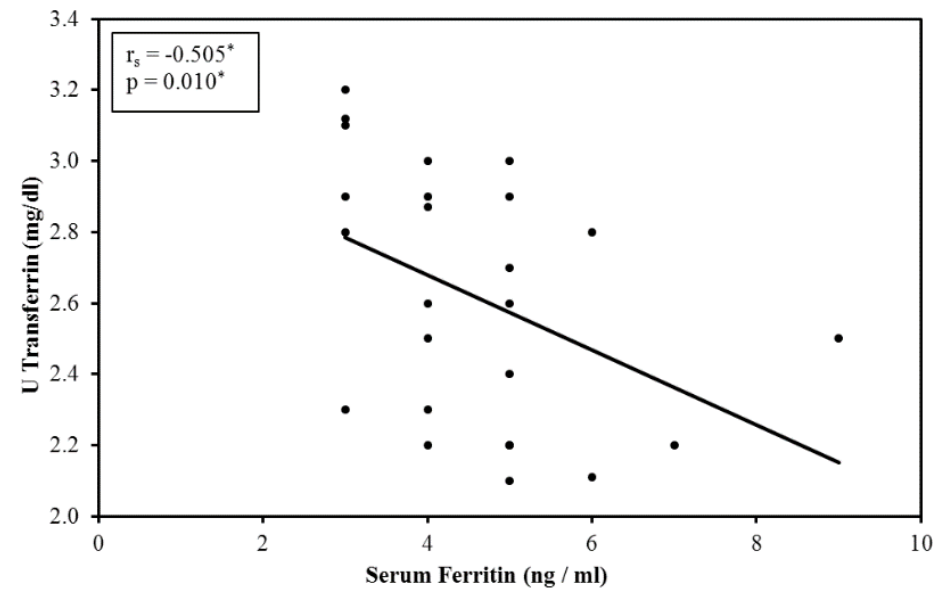

Figure (10): Correlation between serum ferritin $(\mathrm{ng} / \mathrm{ml})$ and $U$ Transferrin $(\mathrm{mg} / \mathrm{dl})$ in Cases in active state (-ve correlation) 
Evaluation of Serum Iron and Transferrin in Idiopathic...

ROC Curve

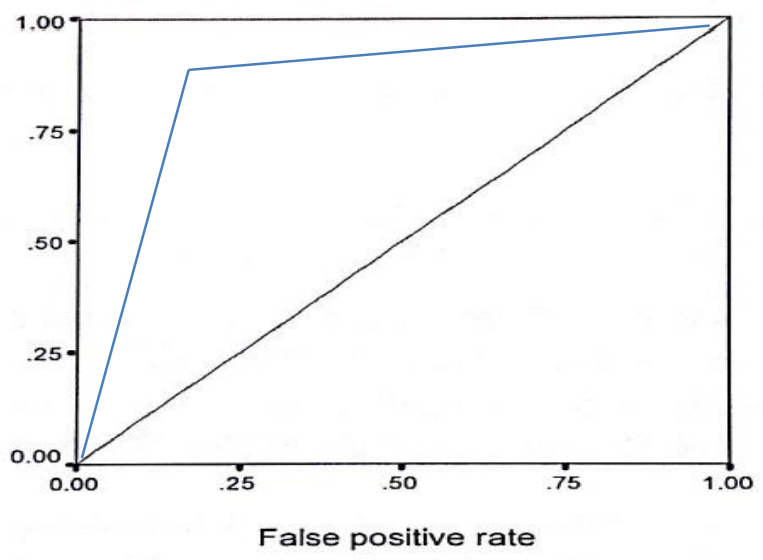

Figure (11): ROC curve for U Transferrin (mg/dl) to predict anemia in cases in active nephrotic syndrome DISCUSSION

Nephrotic syndrome is characterized by marked urinary excretion of albumin and other intermediated-size plasma proteins such as transferrin $^{\cdot(9)}$.

Transferrin is very important glycoprotein for iron transport between sites of absorption and storage and use in the body. Iron transport is through the mucosal cells of the upper small intestine by the plasma protein transferrin. Transferrin synthesis occurs primarily in the liver and related to the level of iron storage ${ }^{(\mathbf{1})}$.

Anemia is observed in patients with NS. Anemia is usually microcytic and hypochromic, typical of iron deficiency, but is resistant to therapy with iron because of serum transferrin loss in large amount in the urine of some nephrotic patients ${ }^{(10)}$.

In an attempt to study some hematologic parameters in children with nephrotic syndrome and to correlate between changes of these parameters and the activity of the disease, we studied 25 nephrotic children in the active state (group I) and another 25 nephrotic children in the remission state (group II). In this study the 2 groups were compared regarding demographic and some clinical data. There was no statistical significant differences regarding sex, age, height, systolic blood pressure and diastolic blood pressure in the 2 studied groups.

In the present study, the mean hemoglobin level, HCT level, and MCV were found to be significantly lower in NS children in active state compared to NS children in remission state
$(\mathrm{P}<0.001)$. Thus, it can be postulated that some patients had hypochromic microcytic anemia. This conclusion is in accordance with that reported by Aviles $\boldsymbol{e t}$ al. ${ }^{(11)}$, who stated that the hypochromic microcytic anemia in nephrotic patients has different etiologies among which are loss of transferrin in urine which is essential for iron metabolism and lead to iron deficiency anemia not responsive to iron therapy.

Also, malabsorption of iron from the intestine as in chronic renal diseases including nephrotic syndrome might be the cause of iron deficiency anemia. In the current study, serum albumin $(1.70-3.0 \mathrm{gm} / \mathrm{dl})$ was very highly significantly decreased $(\mathrm{P}<$ $0.001)$ in cases in active group as compared to cases in remission group $(3.20-4.10 \mathrm{gm} / \mathrm{dl})$. These results agree with the findings of Babitt $\boldsymbol{e t}$ al. ${ }^{(\mathbf{1 2})}$. They explained these results by the fact that proteinuria including albuminuria is the initial and single most diagnostic clinic laboratory finding in patients with N.S.

In the current study, serum iron levels $(0.11-0.33 \mu \mathrm{g} / \mathrm{ml})$ and ferritin levels $(3.0-9.0 \mathrm{ng} / \mathrm{ml})$ were highly significantly decreased $(\mathrm{P}<0.01)$ in active NS patients as compared to cases in remission group $(0.43-1.20 \mu \mathrm{g} / \mathrm{ml})$ and $(86.0-292.0 \mathrm{ng} / \mathrm{ml})$ respectively. These data agree with those of Lu et al. ${ }^{(13) .}$ They reported that the hypochromic microcytic anemia in nephrotic patients is due to decrease in iron concentration.

In the current study, in cases with activity serum transferrin $(106 .-171.0 \mathrm{mg} / \mathrm{dl})$ was also highly significantly decreased $(\mathrm{P}<$ 
0.01) when compared to those in remission state (209.0 - 312.0 $\mathrm{mg} / \mathrm{dl})$. On the other hand urinary transferrin $(2.10-3.2 \mathrm{mg} / \mathrm{dl})$ was very highly significantly increased $(\mathrm{P}<0.001)$ in NS patients in active state as compared to those in remission state $(0.11-0.23$ mg/dl). These results agree with the findings of Lu et al. ${ }^{(13),}$ who reported that serum iron and transferrin levels markedly decreased in NS patients, which may be partially related to the urinary loss of transferrin.

The results of the present study showed a significant negative correlation between serum iron and urinary transferrin in cases with active disease $(r=-0.489)(P<0.013)$. On the other hand, in the same cases a significant positive correlation was detected between serum iron and serum transferrin $(r=0.452) \quad(P<0.023)$. These results agree with those of Lu et al. ${ }^{(13,14)}$. They concluded that in NS patients serum iron, transferrin and erythropoietin levels are markedly decreased in NS patients, which may be partially related to the urinary loss of these elements. Also, they reported that no significant correlation was found regarding clinical and demographic data, which support our study.

Also a significant positive correlation was found between serum iron and HB, $(\mathrm{P}<0.001)$ and $\mathrm{MCV}(\mathrm{P}<0.009)$. These results agree with the findings of Mitchell et al. ${ }^{(15)}$ and Subh et al. (16), who stated that the hypochromic microcytic anemia in nephrotic patients has different etiologies one of them loss of transferrin in urine which is essential for iron metabolism and lead to iron deficiency anemia.

Our work showed also a significant positive correlation between serum transferrin and HB $(\mathrm{P}<0.001)$ and MCV $(\mathrm{P} 0.026)$. This was in accordance with that reported by Mitchell $\boldsymbol{e t}$ al. ${ }^{(15)}$, Subh et al. ${ }^{(16)}$ and Geon ${ }^{(17)}$, who reported that, transferrin and iron are valuable parameters to make the diagnosis of iron deficiency anemia. These results also agree with Bartnikas ${ }^{(18)}$, who reported that transferrin is an abundant serum metal-binding protein best known for its role in iron delivery and it has an essential role in erythropoiesis and iron metabolism. Patients deficient in transferrin exhibit anemia.

Our study also demonstrated that in cases in the active state there was a significant negative correlation between urinary transferrin and $\mathrm{HB}(0.027)$ and $\mathrm{MCV}(\mathrm{P}<0.009)$. This is in accordance with that reported by Subh et al. ${ }^{(16)}$ and Feinstein et

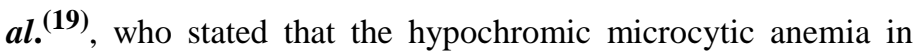
nephrotic patients has different etiologies among which is loss of transferrin in urine.

The present work demonstrated a significant positive correlation between serum transferrin and serum albumin in nephrotic patients with activity $(\mathrm{r}=0.485, \mathrm{P}<0.014)$ and $\mathrm{a}$ significant negative correlation between urinary transferrin and serum albumin $(r=-0.407, P<0.044)$. These findings agreed with those of Lu et al. ${ }^{(13)}$ and Fletcher ${ }^{(20)}$, who reported that serum transferrin was found to correlate closely with albumin, and can be recommended as a useful parameter. In the present study, we found that the urinary transferrin is considered highly valid marker in case of anemia in idiopathic nephrotic syndrome.

Urinary transferrin is a reliable to predict anemia in idiopathic nephrotic syndrome patients $\mathrm{P}<0.0001$ and AUC (area under the curve) is $88 \%$. The best cut off value was $2.8 \mathrm{mg} / \mathrm{dl}$ with a sensitivity of $90 \%$, specificity $84 \%$, PPV $88 \%$ and NPV $75 \%$ with a diagnostic accuracy of $89 \%$ (i.e. Idiopathic nephrotic syndrome patients with urinary transferrin $>2.8 \mathrm{mg} / \mathrm{dl}$ will be anemic).

\section{Conclusion}

The risk of iron deficiency anemia in nephrotic children is more evident during the active stage of the disease as proved by significant changes in the hematological parameters during the activity of the disease. Urinary transferrin is a reliable parameter for prediction of iron deficiency anemia in children with active nephrotic syndrome.

\section{REFERENCES}

1. Papanikolaou G, Pantopoulos K (2017): Systemic iron homeostasis and erythropoiesis. IUBMB life, 69(6):399-413

2. Erdman J, MacDonald I, Zeisel S (2012): Present knowledge in nutrition. John Wiley \& Sons.

3. Abbaspour N, Hurrell R, Kelishadi R (2014): Review on iron and its importance for human health. Journal of research in medical sciences: the official journal of Isfahan University of Medical Sciences, 19(2): 164.

4. Macnair T (2008): Childhood nephrotic syndrome. BBC Health, 8(14):56-57.

5. Morcela D,Kaskel F (2003): Childhood nephrotic syndrome.Information Resources,138(3):4624-4631. . 
6. Keddis M, Bernard M, Karnth H (2007): Nephrotic syndrome. Nephrol; 89(18): 148-153.

7. Monique M (2009): Evaluation of selected parameters of hemostasis in patients with nephrotic syndrome Przegl. Lek., 52(2): 77-81.

8. Johnson A, Rohlfs EM (1999): Tietz Textbook of Clinical Chemistry. Silverman-LM. Protein. Burtis-CA and Ashwood-ER.(Eds.).

9.Kopač M (2018): Nephrotic Syndrome in ChildrenPresent State and Future Perspectives. Journal of Nephrology Research, 4(1): 139-145.

10. Park S, Shin J (2011): Complications of nephrotic syndrome. Korean journal of pediatrics, 54(8): 322-328.

11. Diego A, Iorember F (2017):Anemia in nephrotic syndrome: approach to evaluation and treatment. Pediatric Nephrology, 32(8):1323-1330.

12. Babitt J, Lin $H$ (2012): Mechanisms of anemia in CKD. https://jasn.asnjournals.org/content/23/10/1631

13. Lu H, Yuan Y, Zhang W, Liu D, Kuang H (2006): Concentrations of serum iron and transferrin in children with nephrotic syndrome. Chinese journal of contemporary pediatrics, 8(6):467-469

14. Lu H, Wang L, Fan Q, Liu D, Zhang W, Yuan Y, Kuang H (2008): Serum erythropoietin and transferrin in children with idiopathic nephrotic syndrome. Frontiers of Medicine in China, 2(3):286.
15. Mitchell I, Rubin T, Martin B (2005): Nephrotic syndrome Nephrology textbook, 4th ed. Churchill Livingstone, Edinburgh, London, New York.

16. Subh M, El-Ghannam, M, Nazhif ,Hayam K (2006) : Study of hematologic and hemostatic parameters in children with nephrotic syndrome The Egyptian JournalofPediatrics. https://www.google.com/search?q=(2006)+:+Study+of + he matologic+and+hemostatic+parameters+in+children+with+ nephrotic+syndrome+The+Egyptian+JournalofPediatrics

17. Geon C, Sook J (2009): Soluble transferrin receptor ferritin index and estimated body iron in iron-deficiency anemia in "select" chronic diseases. Annals of Hematology, 88(9): 913-915

18. Bartnikas T B (2012): Known and potential roles of transferrin in iron biology. Biometals, 25(4): 677-686.

19. Feinstein S, Becker-Cohen R, Algur N, Raveh D, Shalev H, Shvil Y, Frishberg Y (2001): Erythropoietin deficiency causes anemia in nephrotic children with normal kidney function. American journal of kidney diseases, 37(4): 736-742.

20. Fletcher (2001): A Comparison of Serum Transferrin and Serum albumin as Nutritional Parameters. https://www.ncbi.nlm.nih.gov/pubmed/3108533. 